\title{
The important role of food composition in policies and programmes for better public health: A South African case study
}

\author{
Prof Hettie C Schönfeldt,
}

Department of Animal and Wildlife Sciences, University of Pretoria, Pretoria, South Africa \& Institute of Food, Nutrition and Well-being, University of Pretoria, Pretoria, South Africa, hettie.schonfeldt@up.ac.za, tel: +27

(0) 12348 6649, PO Box 36802, Menlopark, Pretoria, 0102, South Africa

Dr Nicolette Hall,

Department of Animal and Wildlife Sciences, University of Pretoria,

Pretoria, South Africa \& Institute of Food, Nutrition and Well-being, University of Pretoria, Pretoria, South Africa, nicolette.hall@up.ac.za

Pretorius, B.

Department of Animal and Wildlife Sciences, University of Pretoria, Pretoria, South Africa \& Institute of Food, Nutrition and Well-being, University of Pretoria, Pretoria, South Africa, Beulah.pretorius@up.ac.za

\section{Highlights}

- Food composition data is important for policy development.

- Availability and official access to local data is critical.

- Misreporting can have a costly public health impact.

- Regulations require data for design and enforcement.

\section{Abstract}

Most governments have committed to the set of Sustainable Development Goals established by the United Nations (UN) to be achieved by 2030. Subsequently the governments have drafted, or are in process of drafting, policies and programmes which aim to answer to these global requests. South Africa provides a unique case study: despite economic growth, undernutrition has not improved when 
compared to other industrialised nations, while at the same time, diet-related non-communicable diseases and obesity have exponentially increased. Access to healthy food is a constitutional right of all South Africans, and towards increasing food security and improving population health, various policies, programmes and regulations have been developed and implemented by the government to rectify the situation. The paper presents an overview of food composition within these public health policies, programmes and regulations and unpacks the important role of accurate food composition data.

Key words: food composition, policy, programmes, South Africa

\section{Introduction}

Malnutrition no longer represents the single image of a hungry, undernourished child. The modern norm is that nearly half of governments throughout the world are dealing with populations who are both overweight and undernourished. The quantity of people affected by the different types of malnutrition cannot simply be summed, because a single person can suffer from more than one type of malnutrition. Yet, the scale of malnutrition is confounding. According to the recent Global Nutrition Report, 2 billion people were experiencing micronutrient malnutrition by 2015 , while 1.9 billion adults were overweight or obese. At the same time, 161 million children under the age of 5 are stunted (too short for their age), and 42 million are overweight (International Food Policy Research Institute 2015).

Besides the devastating nature of the statistics, and the fact that nutrition is considered an essential driver for sustainable development, national accountability on nutrition targets vary significantly between countries. As an example, in South Africa, the development of policies, programmes and legislation is largely influenced by international commitments (Hendriks et al. 2016). Such international commitments are translated into national priorities, which are allocated to the relevant governmental departments who set targets and develop policies, programmes and regulations accordingly.

Public health practitioners and policy makers are critical end-users of food composition data (Harrison 2004). Assessing nutrient availability and intakes in populations, developing programs to improve nutritional status, research on diet and disease interrelationships, food system legislation, health education and guidance, preserving indigenous knowledge on traditional and novel foods, and 
predicting or evaluating the effects of policy decisions that affect the food supply all rely on quality food composition data (Harrison 2004). Policies have an influence on food product composition and are aimed to ultimately change dietary composition, but the role which food composition plays is often not recognised to its full potential.

There is a danger that the availability of food composition data readily available over the Internet or from open-access databases could lead to access and misuse of inappropriate or poor quality data that may be irrelevant to the country or food in question. It is important to acknowledge that sound compositional data and an accessible database that is both comprehensive and representative of available foods is an essential basic tool for virtually all quantitative nutrition research, dietary evaluations and the development of food and nutrition policies. There is also a lingering need for a fundamental change in attitudes towards the place of food composition within the nutritional sciences. Food composition data present the primary scientific resource from which all other studies flow (Greenfield \& Southgate 2003).

It is vital for the efficacy and success of public health policies and programmes that food composition data be maintained and developed. Although difficult to quantify, it also makes financial sense. Own, national and accurate data can lower the costs of estimating the exposure of specific population groups to food components that are associated with chronic disease, lessen the frequency of chemical analysis needed in the enforcement of food inspection and food labelling regulations, and it can lower the cost of estimating nutrient and food component intakes from food (Sevenhuysen 1994). The availability of food composition data is also essential for the food industry and food manufacturers, who play an important role in providing healthy foods to consumers.

The positive cost-to-benefit ratio of improving public health (International Food Policy Research Institute 2015) is also substantial enough to motivate the importance of own, quality data to develop successful interventions. Unfortunately, it is difficult to determine the extent to which poor food composition data contribute to uncertainty in research results (Sevenhuysen 1994).

This paper presents a review of the nutrition-sensitive policies, programmes and regulations in South Africa, and unpacks the important role which accurate and unique food composition data plays therein. It also presents an example of the difference in estimations if this is neglected. An overview of the unique South African nutrient situation over time, where obesity has increased while many 
micronutrient deficiencies have persisted, provides evidence to question the accuracy of the nutrient content data used to inform policy development and reform. It provides a good motivation to further promote the need for policy makers to pay more attention on the preparation, extension and maintenance of food composition data and accessible databases. The purpose of this study was to assess the role of food composition in government policies and actions as it impacts the food environment in South Africa. The findings are discussed against achievable, well defined standards of good practices or benchmarks.

\section{Overview of the South African nutrition situation}

The Republic of South Africa, with an estimated population of 53 million (StatsSA, 2016), is a middle income country occupying the southernmost point of the African continent. The country is divided in nine provinces ranging in prosperity and nutritional status of the diversity of cultures residing in each province. Nearly two thirds (62\%) of the population lives in urban areas, with the number consistently increasing due to urbanisation. At the same time many people living in rural areas are commuting daily or weekly to the urban metropoles for their daily jobs (Kirsten, 2012).

South Africa has an abundant supply of natural resources, well developed financial and service sectors and modern infrastructure. The country is considered nationally food secure as agricultural production is high, and at national level there is enough food available for the whole population estimated at more than 3000kcal/capita/day (FAOSTAT, 2013; Schonfeldt, Pretorius \& Hall, 2013). Yet, malnutrition remains a persistent problem. South Africa is in a nutrition transition in which undernutrition (including stunting and micronutrient deficiencies) continue to co-exist with a rising incidence of overweight and obesity and the associated consequences such as hypertension, cardiovascular disease and diabetes (Joubert et al, 2007). Within the context of the acquired immune deficiency syndrome (AIDS) / human immunodeficiency virus (HIV) pandemic and food insecurity, the high prevalence of undernutrition, micronutrient deficiencies and emergent overnutrition presents a complex series of challenges. It needs to be acknowledged that nutrition and health status of individuals are directly linked to their socioeconomic status and culture. Due to the lack of comprehensive data for the each of the diverse population groups, ethnicities and cultures within South Africa, this paper will only present a broad overview at national level. 
The average household income of the poor in South Africa equips many households to procure mainly low cost staple foods such as maize meal porridge, with limited added variety. The poorest consumers (25\% of the population) spend $35 \%$ of their available budget on food (Income and Expenditure Survey, 2010). Although this ability to procure enough food to maintain satiety of all family members may categorise them as being food secure, the nutritional limitations of such monotonous diets might have severe implications in terms of health, development and quality of life. Diet high in energy but low in other essential nutrients such as vitamins and minerals, essential amino acids

Furthermore, as populations modernize as a result of socio-economic development, urbanization and acculturation such as is observed in South Africa, is characterized by changes in dietary patterns and nutrient intakes that increase the risk of the diet-related non-communicable diseases (Vorster, Kruger \& Margetts, 2011). Non-communicable diseases have emerged in Sub-Saharan Africa at a faster rate and at a lower economic level than in industrialized countries, before the battle against undernutrition has been won.

Stunting in children still remains a concern, and is a risk for mortality, poor cognitive and motor development amongst others. More concerning is that stunting usually persists into adulthood, resulting in an adult population with a reduced workforce and higher probability to have a higher BMI (Iversen, Marais, du Plessis \& Herselman , 2012). Stunting incidence has decreased slightly over time from 22.9\% in 1994 (South African Vitamin A Consultative Group, 1996), to 21.6\% in 1999 (Labadarios et al., 1999) and 18\% by 2005 (Labadarios et al., 2008).

Vitamin A deficiency is also prevalent. 33\% of children under 6 years were marginally deficient in vitamin A (serum retinol $<20 \mathrm{mgdL}-1$ ) in 1994 , with the highest rates among 3 to 4 year old children (South African Vitamin A Consultative Group (SAVACG) 1996). By 1999 one out of two children under the age of 9 years consumed less than $50 \%$ of their recommended amount of energy, vitamin A, vitamin $\mathrm{C}$, riboflavin, niacin, vitamin B6, folate, iron, zinc and calcium. In this national study, diets of children were found to be confined to a narrow range of foods of low micronutrient density (Labadarios et al. 1999). Dietary intakes were particularly inadequate in rural areas (Labadarios et al, 2011). 
After the mandatory fortification of staple food with a fortification mix (vitamin A, B-vitamins, zinc and iron) was legislated in October 2003, the follow-up national food consumption survey in 2005 still found significant nutritional deficiencies in children and women. Nearly a third of children and women had anaemia, $64 \%$ of children and $28 \%$ of women had a vitamin A deficiency and $45.3 \%$ of children had a zinc deficiency (Labadarios et al. 2008). In terms of successes, South Africa has essentially achieved the virtual elimination of lodine Deficiency Disorder (IDD) due to the compulsory iodisation of table salt. Table 1 presents an overview of the data on malnutrition reported for the South African population over time.

Table 1: Summary of national nutrition surveillance data over time

\begin{tabular}{|c|c|c|c|c|c|}
\hline $\begin{array}{l}\text { Study year } \\
\text { Reference }\end{array}$ & $\begin{array}{l}1994 \\
\text { SAVACG, } \\
1996\end{array}$ & $\begin{array}{l}1998 \\
\text { DHS, } \\
1998\end{array}$ & $\begin{array}{l}2003 \\
\text { DHS, } \\
2003\end{array}$ & $\begin{array}{l}2005 \\
\text { Labadarios, et al., } \\
2008\end{array}$ & $\begin{array}{l}2012 \\
\text { Shisana, et al., } \\
2013\end{array}$ \\
\hline Vitamin A deficiency children $(<20 \mu \mathrm{g} / \mathrm{dL})$ & $33.3 \%$ & - & - & $63.9 \%$ & $43.6 \%$ \\
\hline Vitamin A deficiency women $(<20 \mu \mathrm{g} / \mathrm{dL})$ & - & - & - & $27.2 \%$ & $13.3 \%$ \\
\hline lodine deficiency $(U \mathrm{I}<100 \mu \mathrm{g} / \mathrm{L})$ & - & $40.9 \%$ & - & $19.2 \%$ & - \\
\hline Anemia $(\mathrm{Hb}<11 \mathrm{~g} / \mathrm{dL})$ & $21.4 \%$ & - & - & $28.9 \%$ & $10.7 \%$ \\
\hline $\begin{array}{l}\text { Iron deficiency anemia }(\mathrm{Hb}<11 \mathrm{~g} / \mathrm{dL} \text {; } \\
\text { Ferratin }<12 \mathrm{ug})\end{array}$ & $5 \%$ & - & - & $11.3 \%$ & $1.9 \%$ \\
\hline Hypertension adults $(\mathrm{BP}>140 / 90 \mathrm{mmHg})$ & - & - & - & - & $10.2 \%$ \\
\hline $\begin{array}{l}\text { Overweight or obesity in adults (men and } \\
\text { women) (BMI > 25) }\end{array}$ & - & - & $56.2 \%$ & - & $64 \%$ \\
\hline
\end{tabular}

SAVACG - South African Vitamin A Consultative Group (1994)

DHS - South African Demographic and Health Survey (1998) \& (2003)

In addition to undernutrition, the prevalence of overweight South Africans is a reality, and increasingly so in children. In 1999 nearly $10 \%$ of South African children under 9 years were recorded as overweight or obese, with $4 \%$ of these being obese (Labadarios et al., 1999). In 2005 , nearly $5 \%$ of children under 5 years of age were recorded as overweight or obese (Labadarios et al., 2008). Of the adult population, $29 \%$ of men and $55 \%$ of women were overweight, and $9 \%$ of men and $29 \%$ of women were obese in 1998 (South African Demographic and Health Survey, 1998). By 2003, 56.2\% of the total adult population was recorded as overweight or obese (South African Demographic and Health Survey, 2003).

In 2000, the Medical Research Council (MRC) performed a comparative risk assessment for South Africa, and found that eleven of the seventeen most common risk factors for deaths were directly or indirectly related to nutrition, and included high blood pressure, excess body weight, high cholesterol, diabetes, low fruit and vegetable intake, vitamin A deficiency and iron deficiency anaemia (Norman et al., 2007). 


\section{National food composition database for reference}

The South African Medical Research Council (MRC) Food Data System (SAFOODS) hosts the national reference tables for food composition. The National Composition Tables of 1991 only contained $18 \%$ local data, with more than $80 \%$ borrowed from around the world, mainly the United States Department of Agriculture Databank (USDA). The latest edition, namely the MRC Condensed Food Composition Tables for South Africa (Wolmerans et al., 2010), was published in 2010. Almost halve of the entries in this update contained South African data (Schönfeldt \& Hall, 2013).

However, since 2010, no new update has been released; despite many local research findings on food composition being published, and many food manufactures having to generate new composition datasets to comply with recent changes to labelling regulations. Many of these food composition studies formed part of formal training at national Universities in partnership with research institutes, relevant industry partners and/or the governmental departments which ensured the quality of the data. The research is available as published data in peer-reviewed journals or as dissertations, theses or formal research reports.

Although substantial and noteworthy differences are often observed between the local research data and borrowed values, the data is generally slow to be taken up within the national database for reference by policy makers. As an example, the composition of lamb and mutton as a favourite food of the South African population, has been determined and published (Schonfeldt, Hall \& Van Heerden 2012; Sainsbury \& Schönfeldt 2011). However, due to a lack of an updated database, the current national reference database still makes reference to the USDA values for mutton and no values are included for lamb. Table 2 depicts the difference between South African lamb and mutton, and the values for mutton from the USDA that is still used as the local reference. Lean South African lamb is commonly consumed by the population, and contains notably less total fat or saturated fatty acids (SFA), cholesterol and total food energy than the values used as a reference. 
Table 2: Comparison of the nutrient composition of raw lean edible portion $(100 \mathrm{~g})$ of South African lamb and mutton (Sainsbury \& Schönfeldt 2011) compared to the values reported in the current Medical Research Council (MRC) food composition reference tables for South Africa as borrowed from the USDA (Wolmarans et al. 2010)

\begin{tabular}{|c|c|c|c|c|}
\hline \multirow{2}{*}{ Nutrients } & \multirow{2}{*}{ Unit } & \multicolumn{2}{|c|}{$\begin{array}{l}\text { Local data (Schonfeldt, Hall \& Van Heerden } \\
\text { 2012) }\end{array}$} & \multirow{2}{*}{$\begin{array}{l}\text { USDA values (Wolmarans et al. } \\
\text { 2010) } \\
\text { Mutton }\end{array}$} \\
\hline & & Lamb & Mutton & \\
\hline Moisture & $g$ & 70.1 & 68.6 & 60.7 \\
\hline Protein (Nx6.25) & $\mathrm{g}$ & 17.8 & 19.2 & 16.9 \\
\hline Fat & $g$ & 11.3 & 11.4 & 21.6 \\
\hline Food energy (calculated) & kJ & 718 & 746 & 1087 \\
\hline Magnesium (Mg) & $\mathrm{mg}$ & 18.7 & 20.7 & 22 \\
\hline Potassium (K) & $\mathrm{mg}$ & 323 & 255 & 230 \\
\hline Sodium (Na) & $\mathrm{mg}$ & 74.4 & 77.5 & 58 \\
\hline Zinc (Zn) & $\mathrm{mg}$ & 1.48 & 2.92 & 3.33 \\
\hline Iron (Fe) & $\mathrm{mg}$ & 1.13 & 2.65 & 1.6 \\
\hline Saturated fatty acids (SFA) & $g$ & 5.29 & 5.83 & 9.47 \\
\hline $\begin{array}{l}\text { Monounsaturated fatty acids } \\
\text { (MUFA) }\end{array}$ & $g$ & 3.90 & 4.40 & 8.86 \\
\hline $\begin{array}{l}\text { Polyunsaturated fatty acids } \\
\text { (PUFA) }\end{array}$ & $g$ & 0.36 & 0.38 & 1.7 \\
\hline Cholesterol & $\mathrm{mg}$ & 61.8 & 49.8 & 72 \\
\hline
\end{tabular}

\section{Regulations and the role of food composition}

\subsection{Food labelling}

In order to bring the South African labelling of foods in line with the international Codex Framework, the Regulations Relating to the Labelling and Advertising of Foodstuffs published by the Minister of Health in terms of the Foodstuffs, Cosmetics and Disinfectants Act, 1972 (Act 54 of 1972), came into effect in March 2012. The Regulations are aimed to ensure that consumers are provided with nutritional, compositional and other information related to foodstuffs manufactured, imported and sold in South Africa. The specific regulations require that if any nutrient-content or health claim is made, a comprehensive composition table needs to be included on the product label. Unfortunately, due to the general lack of a comprehensive national database and the cost implications of having own products analysed, companies are allowed to use internationally reputable food composition tables as a reference source. This has the potential to deliver incorrect data to the South African consumer. One such example is peanut butter illustrated in Table 3. The sodium content of the local product is nearly half that of the USDA values. 
Table 3: The nutrient content of peanut butter as obtained from a locally produced brand of peanut butter, compared to values obtained from the USDA National Nutrient Database for Standard Reference Release 28 (100g)

\begin{tabular}{|c|c|c|c|}
\hline Nutrient & Unit & $\begin{array}{l}\text { Locally produced } \\
\text { peanut butter (label) }\end{array}$ & $\begin{array}{l}\text { USDA Commodity, Peanut } \\
\text { Butter, smooth (United States } \\
\text { Department of Agriculture 2016) }\end{array}$ \\
\hline Protein (Nx6.25) & $\mathrm{g}$ & 20.0 & 21.9 \\
\hline Fat & $g$ & 46.5 & 49.5 \\
\hline Sodium (Na) & $\mathrm{mg}$ & 296 & 476 \\
\hline Saturated fatty acids (SFA) & $g$ & 7.2 & 9.5 \\
\hline Monounsaturated fatty acids (MUFA) & $g$ & 21.9 & 20.7 \\
\hline Polyunsaturated fatty acids (PUFA) & $g$ & 13.5 & 11.3 \\
\hline
\end{tabular}

\subsection{Food Fortification}

On 7 April 2003 regulations pertaining to the mandatory fortification of all maize meal and wheat flour were printed in the South African Government Gazette, published under Act No 54 of 1972 Foodstuffs, Cosmetics and Disinfectants. The regulations apply to any person or company which manufactures, imports, or sells maize meal and/or wheat flour, and foodstuffs which contain $90 \%$ of either maize meal or wheat flour such as bread. The fortification cocktail, consisting of six vitamins and two minerals (ie. vitamins A, B1, B2, B6, niacin, folic acid, iron and zinc) and addition rates were scientifically calculated based on the research and data from two consumption studies (south African Vitamin A Consultative Group, 1994; Labadarios et al., 1999). An official fortification logo (monochromatic or in colour) with an allowed health claim has been developed which may be used voluntarily on the packaging and advertising materials of fortified maize meal and wheat flour. In Table 4 the nutrient content of unfortified and fortified South African maize meal and wheat bread is compared to maize meal and bread products from the United States. Although energy, protein and carbohydrate content is comparable between the products, fortified maize meal contains notably more micronutrients including folate, vitamin A, thiamine and vitamin B6 than the other maize meal or bread products (Table 4). Folate in particular is considerably higher in fortified maize meal (130 and 210 $\mu \mathrm{g} / 100 \mathrm{~g}$ ) than in the other sources ranging between 8 to $42 \mu \mathrm{g} / 100 \mathrm{~g}$. 
Table 4: Nutrient content of fortified and unfortified maize meal and bread (100g raw)

\begin{tabular}{|c|c|c|c|c|c|c|c|c|}
\hline \multirow[b]{2}{*}{ Nutrient } & \multirow[b]{2}{*}{ Unit } & \multicolumn{4}{|l|}{ Maize meal } & \multicolumn{3}{|l|}{ Bread } \\
\hline & & $\begin{array}{l}\text { Unfortified } \\
\text { maize meal, } \\
\text { raw\# }\end{array}$ & $\begin{array}{l}\text { Fortified } \\
\text { maize meal, } \\
\text { raw\# }\end{array}$ & $\begin{array}{l}\text { Whole- } \\
\text { grain corn } \\
\text { flour }^{\wedge}\end{array}$ & $\begin{array}{l}\text { KASHI } \\
\text { Simply } \\
\text { Maize^ }^{\wedge}\end{array}$ & $\begin{array}{l}\text { Fortified } \\
\text { brown } \\
\text { bread\# }\end{array}$ & $\begin{array}{l}\text { Unfortified } \\
\text { brown } \\
\text { bread\# }\end{array}$ & $\begin{array}{l}\text { Bread, } \\
\text { wheat }^{\wedge}\end{array}$ \\
\hline Energy & $\mathrm{kJ}$ & 1360 & 1380 & 1523 & 1553 & 1029 & 1082 & 1117 \\
\hline Protein & $g$ & 7.7 & 7.6 & 8.75 & 7.8 & 9 & 8.6 & 10.7 \\
\hline Carbohydrates & g & 74 & 74.0 & 73.89 & 83.3 & 43 & 44.1 & 48.7 \\
\hline Fat & $g$ & 1.4 & 1.7 & 5.09 & 3.4 & 1.4 & 2 & 3.24 \\
\hline Vitamin A & $\mu \mathrm{gRE}$ & 0 & 184 & * & * & 84 & 0 & 0 \\
\hline Thiamin (B1) & $\mathrm{mg}$ & 0.13 & 0.43 & 0.16 & 0.32 & 0.46 & 0.16 & 0.415 \\
\hline Riboflavin (B2) & $\mathrm{mg}$ & 0.11 & 0.19 & 0.23 & 0.17 & 0.11 & 0.06 & 0.253 \\
\hline Vitamin B6 & $\mathrm{mg}$ & 0.17 & 0.63 & 0.47 & 0.52 & 2.13 & 0.136 & 0.111 \\
\hline Niacin (B3) & $\mathrm{mg}$ & 0.8 & 3.5 & 2.6 & 3 & 8.2 & 2.6 & 5.62 \\
\hline Folate & $\mu g$ & 8 & 210 & * & 16 & 130 & 42 & * \\
\hline Iron & $\mathrm{mg}$ & 0.7 & 2.6 & 1.74 & 2.6 & 4.1 & 1.5 & 3.49 \\
\hline Zinc & $\mathrm{mg}$ & 0.58 & 2.07 & 2.24 & 1.8 & 4.49 & 1.4 & 1.19 \\
\hline
\end{tabular}

${ }^{*}$ No data

^USDA, 1998

\#Wolmarans et al., 2010

The 2005 National Food Consumption Survey Fortification Baseline (NFCS-FB-1) (Table 1) found persistent micronutrient deficiencies in the South African population, with the exception of folic acid status which was found to have significantly improved to an adequate status. It is possible that the normality of folate status in the country may be the first indication that, for a water soluble vitamin, the food fortification program is associated with a beneficial outcome (Labadarios, et al., 2008). This was also the nutrient which had the highest volume difference between unfortified and the fortified comparison (Table 4). The evidence motivates investigation into why fortification did not seem to improve nutritional status of the other micronutrients, and the possibility that it could either be linked to non-compliance, too low dosages of selected nutrients in the fortified foods, or lack of bioavailability of the nutrients once they enter the human body after ingestion.

Compliance of millers was tested in 2010 , followed by the development of a resource-sensitive, selfauditing process. This was followed by a collaborative consultative process regarding the type and form of nutrients added to the multi-mx which may affect bioavailability and stability. The result was a draft amendment to the regulations submitted to Legal Services in September 2015, which included changes in the form of iron from an exclusive NaFeEDTA ingredient, to NaFeEDTA in combination with Ferrous Fumarate with a higher iron activity and also fortifying all wheat flours, not just bread flour. 
The role of accurate data on the fortified food consumed and the correlation with was further illustrated by a comment on a study published in the Journal of Human Nutrition and Dietetics by Spearing, Kolahdooz, Lukasewich, Mathe, Kamis and Sharma (2012) on the composition of composite foods consumed in a rural village within the country (Mclntyre 2012). The authors used the USDA National Nutrient Database for Standard Reference to calculate nutrient contribution from maize meal in the communities' diets, and thus underreported on the fortified nutrients. Table 5 illustrates the difference in the findings by the authors, compared to the estimated nutrient values if the correct data was used in the calculations.

Table 5: Comparison of the micronutrient composition of crumbly and stiff maize meal porridge published by Spearing et al (2012) and if calculated using the South African Food Composition Tables (Wolmarans et al., 2010) (per 100g) (Mclntyre 2012)

\begin{tabular}{|c|c|c|c|c|c|}
\hline \multirow[b]{2}{*}{ Nutrient } & \multirow[b]{2}{*}{ Unit } & \multicolumn{2}{|c|}{ Spearing et al. (2012) } & \multicolumn{2}{|c|}{$\begin{array}{l}\text { South Afican Food Composition } \\
\text { Tables (Wolmarans et al., 2010) }\end{array}$} \\
\hline & & Putupap $^{1}$ & Stifpap $^{2}$ & $\begin{array}{l}\text { Fortified crumbly } \\
\text { maize meal } \\
\text { porridge }(53 \mathrm{~g} \\
\text { water; } 47 \mathrm{~g} \text { maize } \\
\text { meal) }\end{array}$ & $\begin{array}{l}\text { Fortified stiff maize } \\
\text { meal porridge }(73 g \\
\text { water; } 27 \mathrm{~g} \text { maize } \\
\text { meal) }\end{array}$ \\
\hline Vitamin A & $\mu \mathrm{gRAE}$ & 0 & 1.7 & 86 & 40 \\
\hline Thiamin & $\mathrm{mg}$ & 0.62 & 0.11 & 0.43 & 0.23 \\
\hline Riboflavin & $\mathrm{mg}$ & 0.29 & 0.08 & 0.11 & 0.08 \\
\hline Niacin & $\mathrm{mg}$ & 4.5 & 1.0 & 1.1 & 0.6 \\
\hline Pantothenic acid & $\mathrm{mg}$ & 0.4 & 0.1 & 0.21 & 0.12 \\
\hline Vitamin $\mathrm{B}_{6}$ & $\mathrm{mg}$ & 0.03 & 0.05 & 0.30 & 0.20 \\
\hline Calcium & $\mathrm{mg}$ & 4 & 4 & 4 & 4 \\
\hline Magnesium & $\mathrm{mg}$ & 11 & 8 & 43 & 24 \\
\hline Potassium & $\mathrm{mg}$ & 71 & 29 & 135 & 71 \\
\hline Sodium & $\mathrm{mg}$ & 91 & 88 & 8 & 7 \\
\hline Iron & $\mathrm{mg}$ & 2.4 & 0.9 & 2.4 & 1.4 \\
\hline Zinc & $\mathrm{mg}$ & 0.4 & 0.1 & 1.65 & 0.91 \\
\hline
\end{tabular}

'Putu' is equivalent to crumbly maize meal porridge

2 'Stifpap' is equivalent to stiff maize meal porridge.

\subsection{Salt iodisation}

lodine deficiency disorder (IDD) was the earliest micronutrient problem to be identified in South African populations, first reported in 1927. Voluntary iodisation of table salt was introduced in 1954. At the end of 1995, mandatory iodization of food grade salt (40-60ppm) was implemented in South Africa to comply with one of the nutrition goals of the 1990 World Summit for Children that aimed at eradicating IDD by the year 2000. The iodisation of table salt is regulated by the Regulations Relating to Salt (R. 1368 of 21/12/2001) under the Foodstuffs, Cosmetics and Disinfectants Act, 1972 (Act No. 54 of 1972). Compulsory iodisation of table salt $(\mathrm{NaCl})$, as a public health intervention to eliminate iodine deficiency, resulted in dramatic improvements (Table 1). 
However, interestingly, the South African reference food composition tables do not include salt $(\mathrm{NaCl})$ within their recipe calculations (Wolmarans, Danster, Rossouw \& Schonfeldt. 2010). This presents reason to believe that most of the calculated values reported and published within the reference tables are underreporting iodine intake.

\subsection{Salt reduction regulations}

As a result of increasing evidence, national policies to assist in the improvement of the nutrition have thus included policies to restrict dietary intake of certain nutrients of concern. In response to the 2011 United Nations General Assembly High Level Meeting of Heads of State and Governments and the adoption of the Political Declaration on the Prevention and Control of NCDs and the National Summit Declaration NCD Targets to reach by 2020, the South African Department of Health published a Strategic Plan for the Prevention and Control of Non-Communicable Diseases (2013-2017). One of the specific targets set includes the reduction of mean population intake of salt to $<5$ grams per day by 2020 . Related to this is the target to reduce the prevalence of people with raised blood pressure by $20 \%$ by 2020 (Department of Health 2013).

An internal document was drafted in January 2012, after which a stakeholder Consultative meeting was convened in March 2012. The draft Regulations related to the Reduction of Sodium in Certain Foodstuffs was then published for comments in the Government Gazette in July 2012, and in December of the same year a Working Group discussed comments and finalised the regulatory documents which was published in the Government Gazette on 20 March 2013 (R214/2013).

However, from a food chemistry perspective, the role which sodium plays in addition to taste needs to be considered. Salt is used as a functional ingredient in certain formulations, such as dried sausage in South Africa, to preserve the product and also forms part of the integral microstructure of many food products. The optimal balance for positive health outcomes should be found in a scientifically appropriate manner. Related to food safety, salt inhibits microbiological growth due to its ability to lower water activity. In addition to the beneficial role which sodium plays in preservation of foods, the South African processed meat industry provides a unique case study on the role of food composition when formulating regulations of this nature.

Within the Medical Research Council National Food Composition Tables (Wolmarans et al. 2010), the sodium content of sausage, beef \& pork / Boerewors, grilled is stated as $805 \mathrm{mg}$ per $100 \mathrm{~g}$ and the 
values are borrowed from the United States Department of Agricultural (United States Department of Agriculture, 1998). There are no values for raw processed sausage products, and as boerewors is a uniquely traditional South African food product, the validity of the values is questionable. Furthermore, all other values reported for sausages are borrowed from the USDA (United States Department of Agriculture 1998).

The meat industry proposed a survey of the average salt content of current products in this category in the South African market to establish current sodium levels as the values available are outdated. Only once this is known, a realistic reduction target can be established and published as an addendum governing the salt content of "boerewors", "species sausage" (e.g. beef sausage, pork sausage) and "mixed species sausage" (e.g. beef and pork sausage, beef and mutton sausage) as part of the "Regulations governing the composition and labelling of raw boerewors, raw species sausage and raw mixed-species sausage, Government Gazette No. 12854, No. R2718 of 23 November 1990". In general, the portion size and per capita consumption of such products should also be taken into consideration once accurate nutrient content data is available to extrapolate sodium exposure.

\subsection{Regulations on Trans Fats in food}

Regulations (R. 127) was published in February 2011 by the Department of Health as a "Regulation relating to Trans Fat in Foodstuffs", as part of the Foodstuffs, Cosmetics \& Disinfectants Act, 1972 (Act No. 54 of 1972). According to the Regulation, the sale of foods which contain more than the specified maximum trans-fat content of 2 gram per 100 gram of oil or fat, is prohibited. According to definitions in the regulations, industrially produced trans fatty acids (in other words, trans-fats produced by partial hydrogenation of unsaturated oils) and not naturally occurring trans fatty acids are prohibited. As per definition, Conjugated Linoleic Acid (CLA) and its precursor vaccenic acid are not banned and foods that contain natural trans-fats such as CLA in amounts exceeding 2 gram per $100 \mathrm{~g}$, are not disqualified either.

Prior to the final release and as a response to the draft regulations released for comment in 2010, a written recommendation was submitted to The Legislator, Directorate: Food Control. Within the proposed regulations, certain animal products, such as traditional dried sausage, butter and full cream ice-cream, would not have complied with the maximum level of trans-fat permitted per $100 \mathrm{~g}$ foodstuff, 
and the sale of certain fresh meat products would be prohibited in South Africa if the legislation was to be published as originally proposed.

The recommendation submitted included that products from animal origin should be excluded from the proposed legislation, since scientific evidence suggests that health risks associated with industrially-produced trans-fats are not applicable to naturally-produced trans-fats (conjugated linoleic acid (CLA)), found in products from ruminant animals. Epidemiological studies have shown that at levels which they may be consumed in foods ( $1.5 \%$ maximum of total energy intake) trans-fat from animal origin does not alter the fat biomarkers for cardiovascular risk and are not associated with an increase in this risk.

A secondary recommendation was that if the regulations of the law could not exclude trans-fat from animal origin, the respective industries would be allowed a term of three years to collect trans-fat composition data for these food products. Little or no analytically derived trans-fat data exist for South African products in the current food composition tables. The regulations were amended prior to publication to reflect the recommendations, highlighting the importance of recognising the role of food composition within this type of legislation.

\subsection{Biofortification}

Owing to the increased demand for food-based approaches to solve micronutrient deficiencies, biofortification as a strategy was placed on the Codex Alimentarius Nutrition Committee Agenda in 2005 by the Health Canada Representatives of the Government of Canada. However, because of the limited scientific evidence at the time it was not prioritized. HarvestPlus/IFPRI invested significant resources in generating scientific evidence and delivered a conference room document to the Codex Committee on Nutrition and Foods for Special Dietary Uses (CCNFSDU) and then in 2013 the Committee asked for a discussion paper which was prepared by HarvestPlus/IFPRI and Health Canada. The committee reviewed the discussion paper and had a series of questions. A Member Government had to take the process further and so the Governments of Zimbabwe and South Africa volunteered to prepare a revised Discussion Paper. There was a research paper written based on 9 questions raised by the committee and responses were incorporated into the Revised Discussion Paper. The Codex Alimentarius Commission formally approved new work and a Codex electronic 
working group (eWG) was formed in 2014 to develop a formal definition for biofortification, of which South African Government, academia and civil society members participate.

Since 1952, a sweet potato research program has been operational at the Agricultural Research Council (ARC) Roodeplaat Vegetable and Ornamental Plant Institute (ARC-Roodeplaat). Orangefleshed sweet potatoes (OFSP) containing beta-carotene have been included in the ARC program since the 1980s, but the work was aimed mainly at the frozen-food industry. In 1996, ARC expanded its work on OFSP. The program is linked to the Sweetpotato Action for Health and Security in Africa coordinated by the International Potato Centre (Laurie, Faber, Adebola \& Belete, 2015). This renewed program was complemented by a smaller breeding program, started at the University of Pietermaritzburg in 1994.

In Table 6 the nutrient composition of sweet potatoes are presented. The white sweet potatoes were derived from the national food composition reference tables (Wolmarans et al. 2010). The results from a study by (Leighton 2005) on four different orange-fleshed sweet potato cultivars are also included. Although all four orange-fleshed sweet potato cultivars contained significantly more beta-carotene, calcium, magnesium, potassium and phosphorus than the common white cultivar included in the reference table, notable differences between the various cultivars were also observed. The study found statistically significant $(p \leq 0.05)$ differences in these nutrients between the four orange-fleshed varieties. Such data indicated the need for cultivar specific biodiverse data when focusing on biofortification programs as well.

Table 6: Selected nutrient content of different sweet potatoes (100g raw)

\begin{tabular}{|c|c|c|c|c|c|c|}
\hline Nutrients & unit & $\begin{array}{l}\text { Sweet potato, white } \\
\text { flesh, raw, flesh only } \\
\text { (Wolmarans et al. } \\
\text { 2010) }\end{array}$ & $\begin{array}{l}\text { W119 } \\
\text { Orange- } \\
\text { fleshed sweet } \\
\text { potato } \\
\text { (Leighton } \\
2005 \text { ) }\end{array}$ & $\begin{array}{lr}\text { Jewel } & \text { orange- } \\
\text { fleshed } & \text { sweet } \\
\text { potato (Leighton } \\
2005)\end{array}$ & $\begin{array}{l}\text { Resisto, } \\
\text { orange- } \\
\text { fleshed sweet } \\
\text { potato } \\
\text { (Leighton } \\
2005 \text { ) }\end{array}$ & $\begin{array}{l}\text { A15, orange- } \\
\text { fleshed sweet } \\
\text { potato } \\
\text { (Leighton } \\
2005 \text { ) }\end{array}$ \\
\hline Beta- carotene & $\mu g$ & 36 & 4323 & 6853 & 9230 & 6880 \\
\hline Calcium & $\mathrm{mg}$ & 12 & 65.5 & 115 & 143 & 105 \\
\hline Magnesium & $\mathrm{mg}$ & 13 & 18.5 & 19.2 & 16.0 & 13.5 \\
\hline Phosphorus & $\mathrm{mg}$ & 34 & 57.5 & 57.5 & 71.5 & 60.5 \\
\hline Potassium & $\mathrm{mg}$ & 285 & 362 & 324 & 328 & 348 \\
\hline
\end{tabular}




\section{Food promotion}

Making food systems more nutrition-enhancing so that food is available, accessible, diverse and nutritious is important, but so is assisting consumers in making healthy food choices. Apart from nutritional messages, it is recommended that behaviour-change interventions should also combat food waste and contribute to the sustainable use of resources.

\subsection{Food-based Dietary Guidelines}

The South African Food Based Dietary Guidelines (FBDG) were developed to provide an effective tool to eliminate or greatly reduce nutrition-related diseases. The guidelines are food-based rather than nutrient-based and recommend a food consumption pattern that South Africans five years and older should be following (whether under, over or adequately nourished). Separate guidelines, in line with the general guidelines, were also developed for children under the age of five. New updated South Africa Food-Based Dietary Guidelines have been released in 2012. A Food Guide which serves as a visual reminder to support the messages of the Guidelines for Healthy Eating has also been drafted, tested and adopted. This includes information on the suggested amounts of foods needed daily, from all the food groups. Although having access to enough food to alleviate hunger is often used as a simple benchmark to define being food secure, a diet dominated by low cost staples is far from being nutritionally adequate or in meeting basic FBDGs.

\section{Conclusions}

Food composition plays an important role in policies and programmes towards better nutrition. With the global focus on healthy, sustainable diets and the new set of Sustainable Development Goals (SDG) to achieve by 2030, governmental around the globe are implementing actions to improve nutritional status of their populations. In South Africa various such programmes and regulations have been implemented, but the role of food composition therein is mostly not recognised, while at other times more focus should be paid to the actual nutritional contribution at nutrient level which such interventions would make to the diet of the population. If incorrect data is used, the impact can be adverse.

The generation and scientific publication of new composition data of local and commonly consumed foods are essential, but if the foods are not taken up within the national reference sources of policy- 
makers, they have limited impact within policies and programme designs. As an example, the nutrient content of lamb and mutton are still referenced as from the USDA despite local data being available, as the new data has not been officially released as part of the local reference database of the MRC. The lack of local data availability and access is unfortunate and can result in notable differences in estimations. If international databases are used when calculating nutrients from for example staple foods which are in fact fortified locally, there are notable misreporting of the specific populations' nutrient intake (Schönfeldt, Pretorius \& Hall, 2013). Similarly, allowing international values on product labels could mislead consumers to a large extend because the locally produced product with a unique formulation has a notably different nutrient composition than what is often presented on the label if values are borrowed. The importance of local composition data needs to be further recognised when designing regulations aimed at controlling specific nutrients in foods such as sodium or trans fats, specifically for baseline values or enforcement, and finally dietary promotion replies on accurate composition data of the most commonly consumed foods to disseminate and educate the population on how to correctly achieve a nutritionally adequate diet. Similar to this case study, the importance of food composition in policies and programmes throughout the world needs to be further emphasized and recognised.

\section{References}

Department of Health 2013, 'Strategic Plan for the Prevention and Control of Non-Communicable

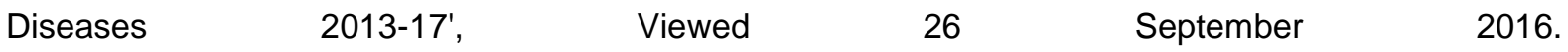
http://www.hsrc.ac.za/uploads/pageContent/3893/NCDs\%20STRAT\%20PLAN\%20\%20CONTENT\%2 08\%20april\%20proof.pdf, Department of Health, Pretoria.

Greenfield, H., \& Southgate, D.A.T. (2003). Food Composition Data - Production, Management and Use. Food and Agriculture Organization of the United Nations, Rome. Viewed 13 September 2016. http://www.fao.org/fileadmin/templates/food_composition/images/FCD.pdf

Harrison, G.G. (2004). Fostering data quality in food composition databases: applications and implications for public health. Food Policy, 33(6), 465-469. 
Hendriks, S., Mkandawire, E., Hall, N., Oliver, N.J., Schönfeldt, H.C., Babu, S., \& Haggblade, S. (2016). Report: Micronutrient Policy Change in South Africa: Implication for the Kaleidescope Model. Working Paper Innovation Lab for Food Security Policy, C3-5.

Income and Expenditure Survey. (2010). Statistical Release from Statistics South Africa. Viewed on 26 September 2016: www.statssa.gov.za/publications/P0100/P01002011.pdf

International Food Policy Research Institute. (2015). Global Nutrition Report 2015: Actions and Accountability to Advance Nutrition and Sustainable Development. Washington, D.C. Viewed 13 September 2016. http://www.fao.org/fileadmin/user_upload/raf/uploads/files/129654.pdf

Iversen, P. O., Marais, D., du Plessis, L. and Herselman, M. (2012). Assessing nutrition intervention programmes that addressed malnutrition among young children in South Africa between 1994-2010. African Journal of Food, Agriculture, Nutrition and Development, 12(2), 5928-5945

Joubert, J., Norman, R., Bradshaw, D., Goedecke, J.H., Steyn, N.P., Puoane, T. and the South African risk assessment collaborating group (2007). Estimating the burden of disease attributable to excess body weight in South Africa in 2000. South African Medical Journal 97(8):683-690.

Kirsten, J.F. (2012). The political economy of food price policy in South Africa. UNU-WIDER Working paper No. 2012/102. UNU World Institute for Development Economics Research (UNU-WIDER)

Labadarios, D., Steyn, N.P., Maunder, E., Maclntyre, U., Swart, R., Gericke, G., Huskisson, J., Dannhauser, A., Voster, H.H., \& Nesamvuni, A.E. (1999). The National Food Consumption Survey: Children aged 1-9 years, South Africa 1999. Viewed 14 March 2014. $<h$ ttp://www.sahealthinfo.org/nutrition/foodtitle.pdf>.

Labadarios, D., Swart, R., Maunder, E.M.W., Kruger, H.S., Gericke, G.J., Kuzwayo, P.M.N., Ntsie, P.R., Steyn, N.P., Schloss, I., Dhansay, M.A., Jooste, P.L., Dannhauser, A., Nel, J.H., Molefe, D., \& Kotze, T.J. (2008). The National Food Consumption Survey - Fortification Baseline (NFCS-FB-1): South Africa, 2005. South African Journal of Clinical Nutrition, 21(3), 245-300.

Laurie, S.M., Faber, M., Adebola, P., \& Belete, A. (2015). Biofortification of sweet potato for food and nutrition security in South Africa. Food Research International. 76, 962-970. 
Leighton, C.S. (2005). Nutrient and sensory quality of orange-fleshed sweet potato. MSc Thesis, $\begin{array}{llllll}\text { University } & \text { of } & \text { Pretoria. } & \text { Viewed } & 13 & \text { September }\end{array}$ http://repository.up.ac.za/dspace/bitstream/handle/2263/28114/Complete.pdf?sequence=10\&isAllowe $\mathrm{d}=\mathrm{y}$

McIntyre, U. (2012). A comment on Spearing et al., 2012 Nutritional composition of commonly consumes composite dishes from rural villages in Empangeni, Kwa-Zulu Natal. South Africa. Viewed 28 April 2016. <https://journalofhumannutritionanddieteticseditor.wordpress.com/2013/03/08/acomment-on-spearing-et-al-2012-nutritional-composition-of-commonly-consumes-composite-dishesfrom-rural-villages-in-empangeni-kwa-zulu-natal-south-africa/>.

Norman, R., Bradshaw, D., Schneider, M., Joubert, J., Groenewald, P., Lewin, S., Steyn, K., Vos, T., Loubscher, R., Nannan, N., Nojilana, B., Pieterse, D. and the South African comparative risk assessment collaborating group. (2007). A comparative risk assessment for South Africa in 2000: towards promoting health and preventing disease. South African Medical Journal 97(8):637-641.

Shisana, O., Labadarios, D., Rehle, T., Simbayi, L., Zuma, K., Dhansay, A., Reddy, P., Parker, W., Hoosain, E., Naidoo, P., Hongoro, C., Mchiza, Z., Steyn, N.P., Dwane, N., Makoae, M., Maluleke, T., Ramlagan, S., Zungu, N., Evans, M.G., Jacobs, L. (2013). South African National Health and Nutrition Examinaiton Survey (SANHANES-1). HSRC Press, Cape Town. Viewed 13 September 2016. http://www.hsrc.ac.za/uploads/pageNews/72/SANHANES-

launch\%20edition\%20(online\%20version).pdf

Sainsbury, J., \& Schönfeldt, H.C. (2011). The nutrient composition of South African mutton. Journal of Food Composition and Analyses, 24, 720-726.

Schönfeldt, H.C., \& Hall, N. (2013). Capacity building in food composition for Africa. Food Chemistry, $140,513-519$.

Schönfeldt, H.C., Pretorius B., \& Hall, N. (2013). The impact of animal source food products on human nutrition and health. South African Journal of Animal Science, 41(3), 394-412.

Sevenhuysen, G.P. (1994). Food composition databases: Current problems and solutions. FAOFPND, 1994. Viewed 13 September 2016. http://www.fao.org/docrep/v6000t/v6000t05.htm 
South African Demographic and Health Survey. 2003. Viewed 26 September 2016. Available online at http://www.info.gov.za/view/DownloadFileAction?id=90143.

South African Demographic and Healthy Survey. 1998. Viewed 26 September 2016. Available online at http://www.doh.gov.za/facts/1998/sadhs98/

South African Vitamin A Consultative Group (SAVACG). (1996). Anthropometric, vitamin A, iron and immunisation coverage status in children aged 6-71 months in South Africa, 1994. South African Medical Journal, 86(4), 354-357.

Spearing, K., Kolahdooz, H., Lukasewich, M., Mathe, N., Khamis, T., \& Sharma, S. (2012). Nutritional composition of commonly consumed composite dishes from rural villages in Empangeni, KwaZuluNatal, South Africa. Journal of Human Nutrition and Dietetics, 26(3), 222-229.

StatsSA (2013). Mid-year population estimates. Statistical release P0302. Statistics South Africa, Private Bag X44, Pretoria, South Africa. Viewed on 26 September 2016. http://www.statssa.gov.za/publications/statsdownload.asp?PPN=P0302\&SCH=5500

United States Department of Agriculture (USDA). (1998). National Nutrient Database for Standard $\begin{array}{llllll}\text { Reference, } & \text { Release } & 12, & \text { viewed } & 12 & \text { July }\end{array}$ <https://www.ars.usda.gov/SP2UserFiles/Place/12354500/Data/SR24/nutrlist/sr24a203.pdf>.

Vorster, H.H., Kruger, A. and Margetts, B.M. (2011). The nutrition transition in Africa: can it be steered into a more positive direction? Nutrients 3(4):429-441.

Wolmarans, P., Danster, N., Dalton, A., Rossouw, K., \& Schönfeldt, H.C. (2010). Condensed Food Composition Tables for South Africa. Medical Research Council, Cape Town. ISBN: 1-919809-63-5 